\title{
Novel aziridine-containing peptides MBJ-0034 and MBJ-0035 from Streptosporangium sp. 32552
}

\author{
This article has been corrected since Advance Online Publication, and a corrigendum is also printed in this issue.
}

\author{
Teppei Kawahara ${ }^{1}$, Masashi Itoh ${ }^{2}$, Miho Izumikawa ${ }^{1}$, Noriaki Sakata ${ }^{2}$, Toshio Tsuchida ${ }^{2}$ and Kazuo Shin-ya ${ }^{3}$
}

The Journal of Antibiotics (2014) 67, 577-580; doi:10.1038/ja.2014.19; published online 12 March 2014

Keywords: aziridine; peptide; Streptosporangium

Recently, we have constructed a library of isolated natural products ( $\mathrm{CB}$ library) primarily of microbial origin, in order to perform efficient screenings. ${ }^{1}$ During the exploration of rare microbial products with promising biological and pharmacological properties, we have developed an advanced system for compound identification based on accumulated HPLC-MS profiling data and strain information designated as 'MBJ's special selection'. Using this system, we have already succeeded in discovering novel eremophilane derivatives MBJ-0009 and MBJ-0010 from Nectria sp. f26111, ${ }^{2} \mathrm{MBJ}-0011, \mathrm{MBJ}-0012$ and MBJ-0013 from Apiognomonia sp. $\mathrm{f} 24023,{ }^{3}$ cytotoxic chaetoglobosin derivatives MBJ-0038, MBJ-0039 and MBJ-0040 from Chaetomium sp. f24230, ${ }^{4}$ and a cytotoxic hydroxamate MBJ-0003 from Micromonospora sp. 29867.5 During the course of further screening, we discovered two aziridinecontaining linear peptides MBJ-0034 (1) and MBJ-0035 (2) from the culture of Streptosporangium sp. 32552 (Figure 1a). Herein, we report the fermentation, isolation, structure elucidation and in brief, the biological activities of $\mathbf{1}$ and 2 .

The producing microorganism Streptosporangium sp. 32552 was isolated from a plant sample collected in Iwata, Shizuoka Prefecture, Japan. The strain was cultivated in 250-ml Erlenmeyer flasks, each containing $25 \mathrm{ml}$ of a seed medium consisting of $2 \%$ potato starch (Tobu Tokachi Nosan Kako Agricultural Cooperative Assoc., Hokkaido, Japan), 2\% glucose (Junsei Chemical, Tokyo, Japan), 2\% soy bean powder (SoyPro, J-Oil Mills, Tokyo, Japan), $0.5 \%$ yeast extract powder (Oriental Yeast, Tokyo, Japan), 0.25\% $\mathrm{NaCl}$ (Junsei Chemical), $0.32 \% \mathrm{CaCO}_{3}$ (Wako Pure Chemical Industries, Osaka, Japan), $0.0005 \% \mathrm{CuSO}_{4} \cdot 5 \mathrm{H}_{2} \mathrm{O}$ (Wako Pure Chemical), $0.0005 \% \mathrm{ZnSO}_{4} \cdot 7 \mathrm{H}_{2} \mathrm{O}$ (Wako Pure Chemical Industries) and $0.0005 \% \mathrm{MnCl}_{2} \cdot 4 \mathrm{H}_{2} \mathrm{O}$ (Junsei Chemical) ( $\mathrm{pH}$ 7.4). The flasks were shaken on a rotary shaker $(220$ r.p.m. $)$ at $28^{\circ} \mathrm{C}$ for 3 days. Then, the aliquots $(0.5 \mathrm{ml})$ of the broth were transferred to 500-ml Erlenmeyer flasks containing $50 \mathrm{ml}$ of the production medium of the same composition and were cultured on a rotary shaker (220 r.p.m.) at $28^{\circ} \mathrm{C}$ for 4 days.

The whole culture broth (21) was extracted with an equal volume of $n-\mathrm{BuOH}$. After the $n$ - $\mathrm{BuOH}$ layer was evaporated in vacuo, the resulting residue was suspended in brine $(350 \mathrm{ml})$ and then extracted with EtOAc $(350 \mathrm{ml} \times 3)$ and $n$ - $\mathrm{BuOH}(300 \mathrm{ml} \times 2)$, successively. The $n$ - $\mathrm{BuOH}$ extract $(3.1 \mathrm{~g})$ was subjected to reversed-phase mediumpressure liquid chromatography (Purif-Pack ODS-30, size: 60 (39g), Shoko Scientific Co., Ltd., Yokohama, Japan) with the UV detection wavelength set at $254 \mathrm{~nm}$. A $\mathrm{H}_{2} \mathrm{O}-\mathrm{CH}_{3} \mathrm{CN}$ stepwise gradient system $\left(100 \mathrm{ml}\right.$ each of $10,20,30,40$ and $\left.50 \% \mathrm{CH}_{3} \mathrm{CN}\right)$ was used to eluate $\mathbf{1}$ (63.2 mg, $\left.40 \% \mathrm{CH}_{3} \mathrm{CN}\right)$. The EtOAc extract $(2.4 \mathrm{~g})$ was fractionated by medium-pressure silica gel column chromatography (Purif-Pack SI-30, size: $60(27 \mathrm{~g})$, Shoko Scientific) using an $n$-hexane-EtOAc linear gradient system (0-25\% EtOAc over $12 \mathrm{~min}$ and was kept at $25 \%$ for $3 \mathrm{~min}$, flow rate: $20 \mathrm{ml} \mathrm{min}^{-1}$ ) followed by a $\mathrm{CHCl}_{3}-\mathrm{MeOH}$ stepwise gradient system $(100 \mathrm{ml}$ each of $0,2,5,10,20,30$ and $100 \%$ $\mathrm{MeOH})$. The $20 \% \mathrm{MeOH}$ fraction $(288.1 \mathrm{mg}$ ) was subjected to gel filtration chromatography (Sephadex LH-20, GE Healthcare BioSciences AB, Uppsala, Sweden; $2.5 \times 45 \mathrm{~cm})$ and eluted using $\mathrm{CHCl}_{3}-\mathrm{MeOH}(1: 1)$ to afford crude $2(63.5 \mathrm{mg})$. The final purification of $2(11.9 \mathrm{mg})$ was carried out by reversed-phase HPLC using a CAPCELL PAK C18 MGII column $(5.0 \mu \mathrm{m}, 20 \times 150 \mathrm{~mm}$; Shiseido, Tokyo, Japan) with $35 \%$ aqueous $\mathrm{CH}_{3} \mathrm{CN}$ containing $0.1 \%$ formic acid (flow rate: $10 \mathrm{ml} \mathrm{min}^{-1}$, retention time: $12.5 \mathrm{~min}$ ).

MBJ-0034 (1) was isolated as a colorless amorphous powder: $[\alpha]^{25} \mathrm{D}+0.6(c 0.1, \mathrm{MeOH}) ; \mathrm{UV} \lambda_{\max } \mathrm{nm}(\log \varepsilon): 241(4.2)$ and 305 (3.8) in $\mathrm{MeOH}$; IR (ATR) $v_{\max } 3300$ and $1650 \mathrm{~cm}^{-1}$ (hydroxy and carbonyl). The molecular formula of 1 was established as $\mathrm{C}_{26} \mathrm{H}_{37} \mathrm{~N}_{7} \mathrm{O}_{9}$ by HR-ESIMS $\left(m / z 590.2560[\mathrm{M}-\mathrm{H}]^{-}\right.$, calcd for $\mathrm{C}_{26} \mathrm{H}_{36} \mathrm{~N}_{7} \mathrm{O}_{9}$ : 590.2575). The peptide-like nature of 1 was evident from the NMR resonances corresponding to amide $\mathrm{NH}$ protons $\left(\delta_{\mathrm{H}} 8.49-7.91\right)$ and the resonances corresponding to the carbonyl carbons $\left(\delta_{\mathrm{C}} 165.1-\right.$

\footnotetext{
1Japan Biological Informatics Consortium (JBIC), Koto-ku, Tokyo, Japan; ²Bioresource Laboratories, MicroBiopharm Japan Co., Ltd. (MBJ), Iwata, Shizuoka, Japan and ${ }^{3}$ National Institute of Advanced Industrial Science and Technology (AIST), Koto-ku, Tokyo, Japan

Correspondence: Dr K Shin-ya, National Institute of Advanced Industrial Science and Technology (AIST), 2-4-7 Aomi, Koto-ku, Tokyo 135-0064, Japan.

E-mail: k-shinya@aist.go.jp
}

Received 19 November 2013; revised 4 February 2014; accepted 14 February 2014; published online 12 March 2014 
<smiles>[R][R]OS(C)(=O)=O</smiles>

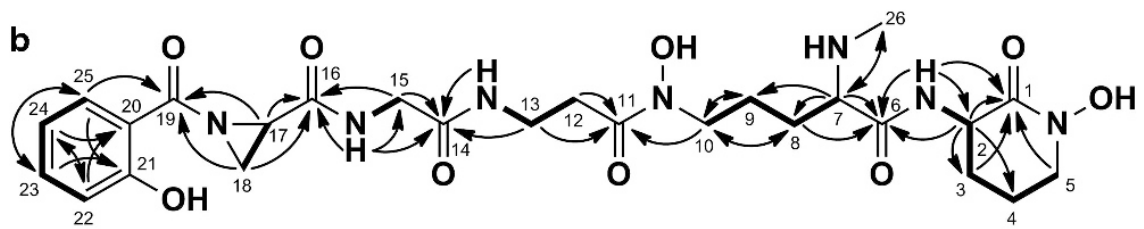

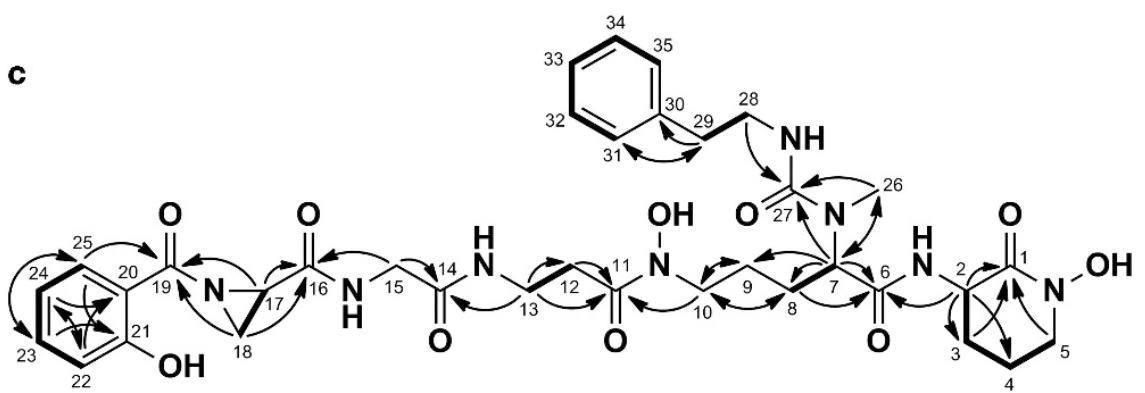

Figure 1 (a) Structures of 1 and 2. (b) Structure determination of 1 . COSY and $\mathrm{HMBC}\left({ }^{1} \mathrm{H}\right.$ to $\left.{ }^{13} \mathrm{C}\right)$ correlations are shown as bold lines and arrows, respectively. (c) Structure determination of 2 . COSY and $\mathrm{HMBC}\left({ }^{1} \mathrm{H}\right.$ to $\left.{ }^{13} \mathrm{C}\right)$ correlations are shown as bold lines and arrows, respectively.

173.7) in the ${ }^{1} \mathrm{H}$ and ${ }^{13} \mathrm{C}$ NMR spectra, respectively. The planar structure of 1 was determined by a series of $2 \mathrm{D}$ NMR analyses including double quantum filtered COSY (DQF-COSY), heteronuclear single quantum coherence and constant-time heteronuclear multiple-bond correlation ${ }^{6}$ (CT-HMBC). The ${ }^{13} \mathrm{C}$ and ${ }^{1} \mathrm{H}$ NMR data of $\mathbf{1}$ is listed in Table 1.

The CT-HMBC spectrum showed a ${ }^{1} \mathrm{H}-{ }^{13} \mathrm{C}$ long-range coupling from a nitrogen-bearing methyl proton $\mathrm{H}_{3}-26\left(\delta_{\mathrm{H}} 2.20, \delta_{\mathrm{C}} 34.4\right)$ to a methine carbon C-7 $\left(\delta_{\mathrm{C}} 63.9\right)$, in which proton $\mathrm{H}-7\left(\delta_{\mathrm{H}} 2.86\right)$ was long-range coupled to an amide carbonyl carbon C-6 ( $\delta_{\mathrm{C}}$ 173.7). Together with these HMBC correlations, the ${ }^{1} \mathrm{H}$ sequence from the $\mathrm{H}-7$ through aliphatic methylene protons $\mathrm{H}_{2}-8\left(\delta_{\mathrm{H}} 1.47,1.40\right)$ and $\mathrm{H}_{2}-9 \quad\left(\delta_{\mathrm{H}} 1.58\right)$ to nitrogen-bearing methylene protons $\mathrm{H}_{2}-10$ $\left(\delta_{\mathrm{H}} 3.46, \delta_{\mathrm{C}} 47.2\right)$ were observed in the DQF-COSY spectrum, indicating the presence of an $\mathrm{N}$-methylornithine moiety (Figure $1 \mathrm{~b}$ ). On the other hand, observation of COSY correlations from a doublet amide $\mathrm{NH}$ proton $2-\mathrm{NH}\left(\delta_{\mathrm{H}} 8.09\right)$ through an $\alpha$-methine proton $\mathrm{H}-2$ $\left(\delta_{\mathrm{H}} 4.31\right)$, aliphatic methylene protons $\mathrm{H}_{2}-3\left(\delta_{\mathrm{H}} 1.93,1.68\right)$ and $\mathrm{H}_{2}-4$ $\left(\delta_{\mathrm{H}} 1.88\right)$ to nitrogen-bearing methylene protons $\mathrm{H}_{2}-5\left(\delta_{\mathrm{H}} 3.45\right.$, $\delta_{\mathrm{C}}$ 51.4) and $\mathrm{HMBC}$ correlations from $\mathrm{H}-2, \mathrm{H}_{2}-3$ and $\mathrm{H}_{2}-5$ to an amide carbonyl carbon $\mathrm{C}-1\left(\delta_{\mathrm{C}} 165.1\right)$ revealed the presence of a $\delta$-lactam of an ornithine moiety.

The presence of a $\beta$-alanine moiety was ascertained by ${ }^{1} \mathrm{H}-{ }^{1} \mathrm{H}$ spin systems from $\alpha$-methylene protons $\mathrm{H}_{2}-12 \quad\left(\delta_{\mathrm{H}}\right.$ 2.51) through $\beta$-methylene protons $\mathrm{H}_{2}-13\left(\delta_{\mathrm{H}} 3.25,3.24\right)$ to a triplet amide $\mathrm{NH}$ proton $13-\mathrm{NH}\left(\delta_{\mathrm{H}} 7.91\right)$ and ${ }^{1} \mathrm{H}-{ }^{13} \mathrm{C}$ long-range couplings from $\mathrm{H}_{2}-$ 12 and $\mathrm{H}_{2}-13$ to an amide carbonyl carbon $\mathrm{C}-11\left(\delta_{\mathrm{C}} 171.1\right)$. The structure of a glycine moiety was determined by ${ }^{1} \mathrm{H}-{ }^{1} \mathrm{H}$ couplings between a triplet amide $\mathrm{NH}$ proton $15-\mathrm{NH}\left(\delta_{\mathrm{H}} 8.49\right)$ and $\alpha$ - methylene protons $\mathrm{H}_{2}-15\left(\delta_{\mathrm{H}} 3.74\right.$, 3.65) together with ${ }^{1} \mathrm{H}-{ }^{13} \mathrm{C}$ long-range couplings from all the protons to an amide carbonyl carbon C-14 ( $\left.\delta_{\mathrm{C}} 168.5\right)$.

The presence of a salicylic acid moiety was established based on a ${ }^{1} \mathrm{H}$ sequence from an aromatic proton $\mathrm{H}-22\left(\delta_{\mathrm{H}} 6.99\right)$ to an aromatic proton $\mathrm{H}-25\left(\delta_{\mathrm{H}} 7.63\right)$ through aromatic protons $\mathrm{H}-23\left(\delta_{\mathrm{H}} 7.46\right)$ and $\mathrm{H}-24\left(\delta_{\mathrm{H}} 6.94\right)$, in addition to HMBC correlations from $\mathrm{H}-23$ and $\mathrm{H}-25$ to an oxygen-bearing aromatic quaternary carbon C-21 $\left(\delta_{\mathrm{C}} 159.2\right)$, from $\mathrm{H}-22$ and $\mathrm{H}-24$ to an aromatic quaternary carbon C-20 $\left(\delta_{\mathrm{C}} 110.1\right)$, and from $\mathrm{H}-25$ to an amide carbonyl carbon C-19 $\left(\delta_{\mathrm{C}}\right.$ 166.0). Furthermore, HMBC correlations from an $\alpha$-methine proton $\mathrm{H}-17\left(\delta_{\mathrm{H}} 5.00\right)$ and methylene protons $\mathrm{H}_{2}-18$ $\left(\delta_{\mathrm{H}} 4.64,4.51\right)$, which were mutually ${ }^{1} \mathrm{H}$ spin coupled, to amide carbonyl carbons C-16 $\left(\delta_{\mathrm{C}} 170.3\right)$ and C-19, revealed the presence of an aziridine moiety, which was acylated with the salicylic acid at the $N$-terminus.

The connectivity among the amino-acid units was determined by ${ }^{1} \mathrm{H}-{ }^{13} \mathrm{C}$ long-range couplings from $\mathrm{H}-2, \mathrm{H}_{2}-10, \mathrm{H}_{2}-13$ and $\mathrm{H}_{2}-15$ to C-6, C-11, C-14 and C-16, respectively. The molecular formula indicated the presence of two hydroxamic acid groups in 1 . The chemical shift value of C-26 $\left(\delta_{\mathrm{C}} 34.4\right)$ suggested that the nitrogen atom connected to C-7 is protonated. ${ }^{7}$ Accordingly, the positions of two hydroxamic acid groups were determined to be C-1 (C-5) and C-10 (C-11). Thus, the gross structure of 1 was elucidated, as shown in Figure 1a.

MBJ-0035 (2) was obtained as a colorless amorphous powder: $[\alpha]^{25}-52$ (c 0.1, MeOH); UV $\lambda_{\max } \mathrm{nm}(\log \varepsilon): 240$ (4.1) and 305 (3.7) in $\mathrm{MeOH}$; IR (ATR) $v_{\max } 3300$ and $1650 \mathrm{~cm}^{-1}$ (hydroxy and carbonyl). The molecular formula of $\mathbf{2}$ was established as 
Table $1{ }^{13} \mathrm{C}$ and ${ }^{1} \mathrm{H}$ NMR spectroscopic data for MBJ-0034 (1) in DMSO- $d_{6}$ and MBJ-0035 (2) in $\mathrm{CD}_{3} \mathrm{OD}$

\begin{tabular}{|c|c|c|c|c|}
\hline \multirow[b]{2}{*}{ Position } & \multicolumn{2}{|r|}{$1^{\mathrm{a}}$} & \multicolumn{2}{|r|}{$2^{\mathrm{b}}$} \\
\hline & $\delta_{C}$ & $\delta_{H}$, mult $(\mathrm{J}$ in $\mathrm{Hz})$ & $\delta_{C}$ & $\delta_{H}$, mult $(\mathrm{J}$ in $\mathrm{Hz})$ \\
\hline 2 & 49.6 & $4.31, \mathrm{~m}$ & 51.5 & 4.40, dd $(5.4,10.8)$ \\
\hline 3 & 27.9 & $1.93, \mathrm{~m} ; 1.68, \mathrm{~m}$ & 28.6 & $2.03, \mathrm{ovl}^{\mathrm{c}} ; 1.79, \mathrm{~m}$ \\
\hline 4 & 20.5 & $1.88, \mathrm{~m}$ & 21.8 & $1.99, \mathrm{~m} ; 1.95, \mathrm{~m}$ \\
\hline 7 & 63.9 & $2.86, \mathrm{dd}(6.5,6.5)$ & 58.5 & $4.85, \mathrm{ovl}^{\mathrm{C}}$ \\
\hline 8 & 30.4 & $1.47, \mathrm{~m} ; 1.40, \mathrm{~m}$ & 26.7 & $1.86, \mathrm{~m} ; 1.69, \mathrm{~m}$ \\
\hline 9 & 23.0 & $1.58, \mathrm{~m}$ & 24.2 & $1.58, \mathrm{~m} ; 1.52, \mathrm{~m}$ \\
\hline 10 & 47.2 & $3.46, \mathrm{ovl}^{\mathrm{c}}$ & 48.3 & 3.75, ddd $(7.2,14.4,14.4) ; 3.53, \mathrm{ovl}^{\mathrm{c}}$ \\
\hline 11 & 171.1 & & $173.94^{d}$ & \\
\hline 12 & 32.1 & $2.51, \mathrm{ovl}^{\mathrm{c}}$ & 32.9 & $2.73, \mathrm{~m} ; 2.69, \mathrm{~m}$ \\
\hline 17 & 67.6 & $5.00, \mathrm{dd}(8.0,10.5)$ & 69.5 & $5.05, \mathrm{dd}(8.0,10.2)$ \\
\hline 18 & 69.6 & $4.64, \mathrm{dd}(8.0,10.5) ; 4.51, \mathrm{dd}(8.0,8.0)$ & 70.6 & $4.68, \mathrm{dd}(8.0,10.2) ; 4.61, \mathrm{dd}(8.0,8.0)$ \\
\hline 19 & 166.0 & & 168.7 & \\
\hline 20 & 110.1 & & 111.5 & \\
\hline 21 & 159.2 & & 160.9 & \\
\hline 22 & 116.8 & 6.99, d (8.0) & 117.7 & 6.97, d (7.6) \\
\hline 23 & 134.3 & 7.46, ddd $(1.5,8.0,8.0)$ & 135.1 & 7.42, ddd $(1.2,7.6,7.6)$ \\
\hline 24 & 119.3 & $6.94, \mathrm{dd}(8.0,8.0)$ & 120.0 & $6.90, \mathrm{dd}(7.6,7.6)$ \\
\hline 25 & 128.2 & $7.63, \mathrm{dd}(1.5,8.0)$ & 129.6 & $7.69, \mathrm{dd}(1.2,7.6)$ \\
\hline 26 & 34.4 & $2.20, \mathrm{~s}$ & 30.4 & $2.77, \mathrm{~s}$ \\
\hline 27 & & & 161.1 & \\
\hline 28 & & & $43.6^{d}$ & $3.38, \mathrm{ovl}^{\mathrm{c}}$ \\
\hline $\mathrm{NH}$ & & $7.91, \mathrm{t}(6.0)$ & & \\
\hline $\mathrm{OH}$ & & 11.70, br s & & \\
\hline $\mathrm{OH}$ & & $9.56, \mathrm{br} \mathrm{s}$ & & \\
\hline
\end{tabular}

NMR spectra were taken on a Varian NMR System $600 \mathrm{NB} \mathrm{CL}(\mathbf{1})$ or $500 \mathrm{NB} \mathrm{CL}(\mathbf{2})$ in DMSO- $d_{6}(\mathbf{1})$ or $\mathrm{CD}_{3} \mathrm{OD}(\mathbf{2})$ with the residual solvent peak as an internal standard (DMSO- $d_{6}: \delta_{\mathrm{C}} 39.7, \delta_{\mathrm{H}}$ 2.49 p.p.m.; $\mathrm{CD}_{3} \mathrm{OD}: \delta_{\mathrm{C}} 49.0, \delta_{\mathrm{H}} 3.31$ p.p.m.).

a500 MHz.

b600 MHz.

'Overlapped with other signals.

dExchangeable.

$\mathrm{C}_{35} \mathrm{H}_{46} \mathrm{~N}_{8} \mathrm{O}_{10}$ from the HR-ESIMS data $\left(m / z 739.3450[\mathrm{M}+\mathrm{H}]^{+}\right.$, calcd for $\mathrm{C}_{35} \mathrm{H}_{47} \mathrm{~N}_{8} \mathrm{O}_{10}$ : 739.3415).

Based on the analyses of $1 \mathrm{D}$ and $2 \mathrm{D}$ NMR spectra, the partial structure of 2 was found to be the same as that of 1 , as shown in Figure 1c. The structural difference between $\mathbf{1}$ and $\mathbf{2}$ is an additional phenethylcarbamic acid moiety, whose presence was confirmed by ${ }^{1} \mathrm{H}$ sequences from aromatic protons $\mathrm{H}-31 / 35\left(\delta_{\mathrm{H}} 7.21\right)$ through aromatic protons $\mathrm{H}-32 / 34\left(\delta_{\mathrm{H}} 7.27\right)$ to an aromatic proton $\mathrm{H}-33\left(\delta_{\mathrm{H}}\right.$ 7.17) and from nitrogen-bearing methylene protons $\mathrm{H}_{2}-28$ $\left(\delta_{\mathrm{H}} 3.38, \delta_{\mathrm{C}} 43.6\right)$ to allylic methylene protons $\mathrm{H}_{2}-29\left(\delta_{\mathrm{H}} 2.80\right)$, together with $\mathrm{HMBC}$ correlations from $\mathrm{H}_{2}-28$ to carbonyl ketone carbon $\mathrm{C}-27\left(\delta_{\mathrm{C}} 161.1\right)$ and from $\mathrm{H}_{2}-29$ to an aromatic quaternary carbon C-30 $\left(\delta_{\mathrm{C}} 140.9\right)$ and an aromatic methine carbon C-31/35
$\left(\delta_{\mathrm{C}}\right.$ 129.9). Finally, $\mathrm{HMBC}$ correlations from an $N$-methyl proton $\mathrm{H}_{3}-26\left(\delta_{\mathrm{H}} 2.77\right)$ and a low-field shifted $\alpha$-methine proton $\mathrm{H}-7$ $\left(\delta_{\mathrm{H}} 4.85\right)$ to C-27 indicated that the phenethylcarbamic acid moiety is connected to C-7 by an amide bond. Therefore, the structure of 2 was determined as shown in Figure 1a.

The cytotoxic activities of $\mathbf{1}$ and $\mathbf{2}$ against human ovarian adenocarcinoma SKOV-3 cells were examined by using the WST- 8 [5-(2,4-disulfophenyl)-3-(2-methoxy-4-nitrophenyl)-2-(4-nitrophenyl) -2H-tetrazolium, monosodium salt] colorimetric assay (Cell Counting Kit; Dojindo, Kumamoto, Japan). After $72 \mathrm{~h}$ of treatment, 2 exhibited weak cytotoxic activity against SKOV-3 cells with the $\mathrm{IC}_{50}$ of $37 \mu \mathrm{M}$, whereas 1 exhibited no cytotoxicity $\left(\mathrm{IC}_{50}>50 \mu \mathrm{M}\right)$. Since the derivatives of 1 and 2, madurastatin A1 and its congeners 
were reported to show antibacterial activities against Micrococcus luteus, ${ }^{7}$ we evaluated the antimicrobial activities of $\mathbf{1}$ and 2 . As the result, contrary to this report, $\mathbf{1}$ and $\mathbf{2}$ did not show antimicrobial activities against $M$. luteus nor Bacillus subtilis even at the concentrations of $100 \mu \mathrm{M}$. Compounds 1 and 2 did not show the antimicrobial activities against Escherichia coli. To the best of our knowledge, peptides with aziridine moiety is extremely rare in nature and have not been reported except for madurastatin A1. The planar structure of $\mathbf{1}$ appears to be same as madurastatin $\mathrm{C} 1 .^{8}$

\section{ACKNOWLEDGEMENTS}

This work was supported by a grant from the New Energy and Industrial Technology Department Organization (NEDO) of Japan and a Grant-in-Aid for Scientific Research (23380067 to KS-y) from the Japan Society for the Promotion of Science (JSPS).
1 Kawahara, T., Nagai, A., Takagi, M. \& Shin-ya, K. JBIR-137 and JBIR-138, new secondary metabolites from Aspergillus sp. fA75. J. Antibiot. 65, 535-538 (2012).

2 Kawahara, T. et al. Cytotoxic sesquiterpenoids MBJ-0009 and MBJ-0010 from saprobic fungus Nectria sp. f26111. J. Antibiot. 66, 567-569 (2013).

3 Kawahara, T. et al. Three eremophilane derivatives, MBJ-0011, MBJ-0012 and MBJ-0013, from an endophytic fungus Apiognomonia sp. f24023. J. Antibiot. 66, 299-302 (2013)

4 Kawahara, T. et al. New chaetoglobosin derivatives, MBJ-0038, MBJ-0039 and MBJ-0040, isolated from the fungus Chaetomium sp. f24230. J. Antibiot. 66, 727-730 (2013).

5 Kawahara, T. et al. New hydroxamate metabolite, MBJ-0003, from Micromonospora sp. 29867. J. Antibiot. 67, 261-263 (2014).

6 Furihata, K. \& Seto, H. Constant time HMBC (CT-HMBC), a new HMBC technique useful for improving separation of cross peaks. Tetrahedron. Lett. 39, 7337-7340 (1998).

7 Harada, K. et al. Isolation and structural characterization of siderophores, madurastatins, produced by a pathogenic Actinomadura madurae. J. Antibiot. 57, 125-135 (2004).

8 Mazzei, E., Iorio, M., Maffioli, S. I., Sosio, M. \& Donadio, S. Characterization of madurastatin C1, a novel siderophore from Actinomadura sp. J. Antibiot. 65, 267-269 (2012) 